\title{
www.czasopisma.pan.pl \\ Physico-Chemical and Environmental Characterisation of the Dust from Dry Dedusting of the Green Sand
}

\author{
A. Bobrowski*, B. Grabowska, S. Żymankowska - Kumon, Ż. Kurleto-Kozioł \\ AGH University of Science and Technology, Faculty of Foundry Engineering, \\ Reymonta 23, 30-059 Kraków, Poland \\ *Corresponding author. E-mail address: arturb@agh.edu.pl
}

Received 27.04.2016; accepted in revised form 31.05.2016

\begin{abstract}
The article presents research results of physico-chemical and environmental issues for the dust generated during dedusting of the installation for the processing and preparation of moulding sand with bentonite. Particular attention was paid to the content of heavy metals and emission of gases from the BTEX group, which is one of the determinants of the moulding sands harmfulness for the environment. The analysis of heavy metals in the test samples indicate that there is an increase of the content of all metals in the dust compared to the initial mixture of bentonite. The most significant (almost double) increase observed for zinc is probably related to the adsorption of this element on the dust surface by contact with the liquid metal. The study showed, that dust contained more than $20 \%$ of the amount of montmorillonite and had a loss on ignition at a similar level. The addition of $1 \%$ of dust to the used moulding sand results in almost $30 \%$ increase in the total volume of gases generated in casting processes and nearly $30 \%$ increase of the benzene emission.
\end{abstract}

Keywords: Dust, Dedusting, Physico-chemical investigations, Heavy metals, Emission of gases

\section{Introduction}

The primary disadvantage of a moulding sand with bentonite is a loss of binding properties during thermal loads in casting processes, associated with inactivation of bentonite. This process is irreversible. Deactivated bentonite arrears in moulding sand are in the dust form, which must be removed for the technological and economic reasons. Fine dust adversely affects the permeability, which in turn can lead to casting defects, and simultaneously makes it necessary to use higher amounts of bentonite in the refreshing process of green sand [1-5].

In order to improve the properties of used moulding sands with bentonite, a dedusting process is carried out before the next production cycle. Depending on the degree of technological advancement and automation in the foundry this treatment is carried out at various stages of the moulding sand processing. The composition and properties of dust have an influence on the technical conditions such as a power of fans in each section of the used moulding sand processing, the equipment to homogenization but also technological conditions characteristic for the foundry, i.e. humidity and temperature of used moulding sand, a degree of thermal load, refreshing rates, etc. The proper selection of operating parameters of machinery and equipment and the choice of optimal technological properties allows the proper dedusting of used moulding sands and determines the amount of dust generated.

The paper presents research results of the physicochemical properties of the dust produced by dedusting of the used moulding sands in the iron foundry. The research aimed to determine the environmental impact of the dedusting process, in particular the 
content of heavy metals in the dust and gas emissions from moulding sands with the dust addition, was also carried out.

\section{Materials for analysis}

Material for analysis was the dust from the dry dedusting moulding sand with bentonite, from one of the national iron foundries. Dust was collected over a period of 2 weeks. The parameters applied during the dust collection for research: 1. The average moisture of the used moulding sand $-4.5 \%$ 2. The average temperature of the used moulding sand $-39.5^{\circ} \mathrm{C}$.

\section{Results and their discussion}

\subsection{The results of physicochemical tests}

For the collected dust sample the basic physicochemical investigations were performed and compared with the results obtained for a sample of a fresh mixture of bentonite with the lustrous carbon carrier. Table 1 shows the results of the physicochemical parameters of the dust. For comparisons the results are shown with parameters of the fresh mix bentonite lustrous carbon carrier applied to refresh used moulding sand.

The results of the physicochemical tests of the dust from dedusting of the used moulding sand with bentonite, from one of the national iron foundries, indicate that this dust contains many valuable ingredients. The high content of montmorillonite and large loss on ignition indicate that it can be a valuable material for reuse. The dust is alkaline and to a small degree deviates from the $\mathrm{pH}$ of the fresh mix of the bentonite with the lustrous carbon carrier. Almost twofold increase in the conductivity of solutions containing dust shows an increased content of ions capable of carrying electrical charges. In the case of moulding sand with bentonite it can be the effect of the application of the process water, which can contain calcium and magnesium cations and anions of carbonate, chlorine, etc. This phenomenon is even more pronounced in the case of the process water closed circle, where the accumulation of these components can occur.

The ability to create lustrous carbon of the dust decreases drastically and is a direct consequence of burning (pyrolysis) of the lustrous carbon carrier in the casting process.

\subsection{The content of heavy metals}

As part of the environmental studies the contents of the selected heavy metals in the dust from the dry dedusting and from the fresh mixture of bentonite with the lustrous carbon carrier, were analysed. The determination was performed by the ICP, based on the Polish Standard PN-EN ISO 11885: 2001. The process of mineralization of samples was made by a mixture of concentrated hydrochloric acid with nitric acid in a volume ratio of 3: 1 (i.e. Aqua regia) using microwave mineralizer. Table 2 shows the results of tests, per kilo of dry weight. The analysis of heavy metals in the test samples indicate that there is an increase of the content of all metals in the dust compared to the initial mixture of bentonite. The most significant (almost double) increase observed for zinc is probably related to the adsorption of this element on the dust surface by contact with the liquid metal.

Table 1.

Characteristics of the dust dedusting and a mixture of bentonite - lustrous carbon carrier

\begin{tabular}{|c|c|c|c|c|c|}
\hline \multirow[b]{2}{*}{ Sample } & \multicolumn{5}{|c|}{ Tested parameter } \\
\hline & $\begin{array}{l}\text { Montomorillonite } \\
\text { content, [\%] }\end{array}$ & $\begin{array}{c}\text { Lost of } \\
\text { igniton, }[\%]\end{array}$ & $\mathrm{pH}$ & $\begin{array}{c}\text { Electrolytic } \\
\text { conductivity, }[\mathrm{mS} / \mathrm{cm}]\end{array}$ & $\begin{array}{c}\text { Ability to create } \\
\text { lustrous carbon, }[\%]\end{array}$ \\
\hline $\begin{array}{l}\text { Dust from dry dedusting of } \\
\text { green sand }\end{array}$ & 20,75 & 21,30 & 9,45 & 1,04 & 0,33 \\
\hline $\begin{array}{l}\text { Mixture of bentonite with } \\
\text { the lustrous carbon carrier }\end{array}$ & 54,20 & 32,12 & 9,50 & 0,60 & 2,25 \\
\hline
\end{tabular}

Table 2

Content of the selected heavy metals in the dust from dedusting of the used moulding sand with bentonite and from the mix of bentonite with the lustrous carbon carrier

\begin{tabular}{ccc}
\hline \multirow{2}{*}{ Tested component } & \multicolumn{2}{c}{ Content in sample, $[\mathrm{mg} / \mathrm{kg}$.dry weight] } \\
\cline { 2 - 3 } & Mixture of bentonite with the lustrous carbon carrier & Dust from dry dedusting of green sand \\
\hline $\mathrm{Cd}$ & $<0,1$ & $<0,1$ \\
\hline $\mathrm{Cr}$ & 33,0 & 34,1 \\
\hline $\mathrm{Cu}$ & 21,8 & 29,4 \\
\hline $\mathrm{Fe}$ & 10251,0 & 10982,2 \\
\hline $\mathrm{Mn}$ & 318,1 & 376,6 \\
\hline $\mathrm{Ni}$ & 4,1 & 6,5 \\
\hline $\mathrm{Pb}$ & 12,9 & 16,1 \\
\hline $\mathrm{Zn}$ & 32,9 & 55,2 \\
\hline
\end{tabular}




\subsection{The study of gases emissions}

Determination of emissions of gases during a casting process was made in the investigation place (the subject of the patent application P.398709 dated 2012-04-02), developed in the Faculty of Foundry Engineering AGH. Figure 1 shows the scheme of the investigation place.

A sample of the moulding sand is placed in a steel bell, which is situated $1-2 \mathrm{~cm}$ above the bottom surface of the mould cavity. The form is made of the classic moulding sand with bentonite on the basis of quartz. The gases emitted during the liquid metal (cast iron at a temperature of about $1350{ }^{\circ} \mathrm{C}$ ) contact with the test sample of the moulding sand are directed to the specially built capsule, in which they are dried. Then the gases are adsorbed on an activated carbon and the remaining part is caught by a pump combined with recorder, which allows to record the volume of gases [6-10].

The investigations were performed for two samples of the material:

- Moulding sand 1:

- 100 parts by mass - quartz sand; - 2.0 parts by mass - mixture of bentonite - lustrous carbon carrier;

- Moulding sand 2:

- 100 parts by mass - quartz sand;

- 2.0 parts by mass - mixture of bentonite - lustrous carbon carrier;

- 1.0 part by mass - dust from dedusting of moulding sand.

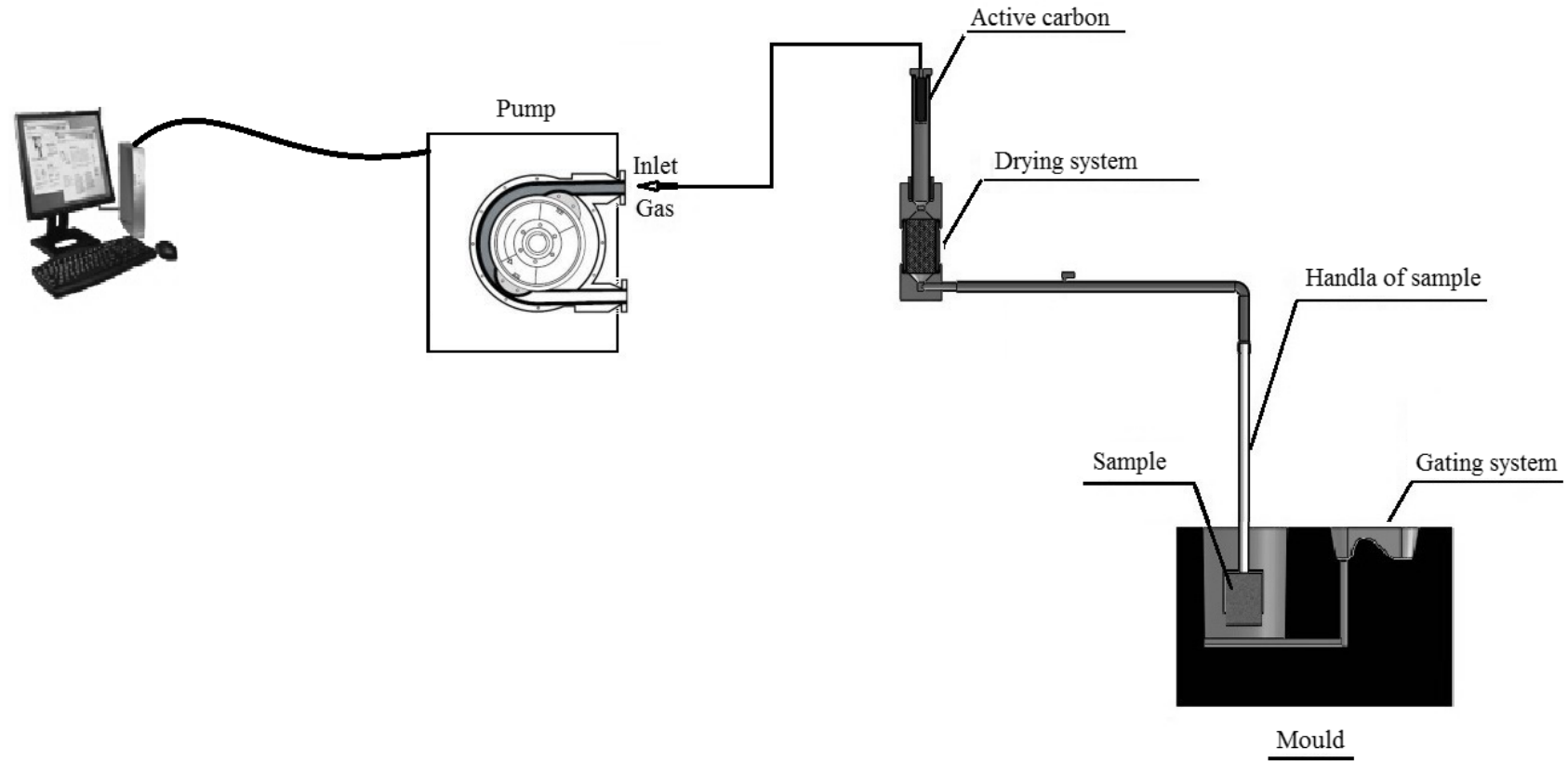

Fig. 1. The scheme of the investigation place for determination of gases emission from moulding sands

Table 3.

The results of gasses emissions from: the fresh moulding sand and moulding sand with addition of 1 part of mass of the dust from the dedusting process

\begin{tabular}{ccc}
\hline Tested & The quantity of component $/ \mathrm{kg} \mathrm{s.m.}$ \\
\cline { 2 - 3 } component & $\begin{array}{c}\text { Sand 1 } \\
\mathrm{W}=3,3 \%\end{array}$ & $\begin{array}{c}\text { Sand } 2 \\
\mathrm{~W}=3,6 \%\end{array}$ \\
\hline $\begin{array}{c}\text { Volume of } \\
\text { gases }\end{array}$ & $20,8 \mathrm{dm} 3$ & $23,2 \mathrm{dm} 3$ \\
\hline Benzene & $258,2 \mathrm{mg}$ & $332,8 \mathrm{mg}$ \\
\hline Toluene & $7,8 \mathrm{mg}$ & $8,5 \mathrm{mg}$ \\
\hline Ethylobenzene & $0,05 \mathrm{mg}$ & $0,07 \mathrm{mg}$ \\
\hline Xylenes & $0,35 \mathrm{mg}$ & $0,37 \mathrm{mg}$ \\
\hline
\end{tabular}

The addition of $1 \%$ of the dust from the dedusting process to the moulding sand increases the total volume of gases emitted from the moulding sand during the casting processes by approximately $11 \%$. Benzene emissions for the analysed case grew by $29 \%$. For the remaining gases from the BTEX group the emission remained at very low level, which was caused by disintegration of these compounds (at a temperature of $1300^{\circ} \mathrm{C}$ ) with creation a basic structure of benzene.

\section{Conclusions}

1. The dust from the dedusting of the moulding sand with bentonite, contains more than $20 \%$ of montmorillonite. The loss on ignition indicates a high content of combustible parts, but the ability to create a lustrous carbon is lost in the technological process.

2. Analysis of heavy metal content showed, that for the dust sample from the dedusting process nearly a double amount of zinc was found. 
3. Addition of the dust to the used moulding sand in an amount of $1 \%$ increases a volume of gases released from a representative sample by about $11 \%$.

4. The largest increases of emissions of compounds from the BTEX group (benzene, toluene, ethylbenzene, xylenes) were recorded for benzene - a growth of about $29 \%$, as compared to the moulding sand without the dust addition.

5. The composition of the dust generated in a dedusting process is dependent on many technological parameters, such as humidity and temperature of the moulding sand, as well as on the optimisation of operating parameters of the installed dedusting equipment.

\section{References}

[1] Tilch, W. (2004). Ermittlung des Aufbereitungsverhaltnes bentonitgebundener Formstoffe (Betribssande). Giesserei Praxis. 1, 12-18.

[2] Grefhorst, C. Podobed, O. \& Böhnke, S. (2005). Bentonitgebundene Formstoffe. Giesserei. 3, 63-67.

[3] Heinrich, M., Pittelkow, Th. \& Hasse, S. (2006). Grosstechnische Umstellung von Bentonit und Glanzkohlenstoff-Bindern in Formstoffsystem. Giesserei Praxis. 4, 105-113.
[4] Bobrowski, A. (2009). Characteristics of dust from dry dedusting of processing station of moudilg sand with bentonite in the aspect of their utility use. $\mathrm{PhD}$ thesis.

[5] Holtzer, M. Bobrowski, A, Grabowska, B, Schindler, A. \& Hodor, K. (2010). Investigation of carriers of lustrous carbon at high temperatures. Archives of Foundry Engineering. 10(spec.1), 225-232

[6] Holtzer, M., Grabowska, B., Żymankowska-Kumon, S., Kwaśniewska-Królikowska, D., Dańko, R., Solarski, W. \& Bobrowski, A. (2012). Harmfulness of moulding sands with bentonite and lustrous carbon carriers. Metalurgija. 51(4), 437-440.

[7] Holtzer, M. \& Bobrowski, A. (2010). Assessment of harmfulness of green sand with additions of dust from dry dedusting. Archives of Foundry Engineering. 10(3), 193-198.

[8] Bobrowski, A. \& Holtzer, M. (2009). Assessment of environmental influence of bentonite and lustrous carbon carrier - in an aspect of gases emission. Archives of Foundry Engineering. 9(1), 21-24.

[9] Holtzer, M. \& Bobrowski, A. (2010). Assessment of harmfulness of green sand with additions of dust from dry dedusting. Archives of Foundry Engineering. 10(3), 193-198.

[10] Holtzer, M. and others (2012). Polish patent No P.398709 dated 2012-04-02. 